\title{
RUSSIAN PAPERS ON LEPROSY
}

\author{
Dr. J. R. InNES, General Secretary-Treasurer, \\ International Leprosy Association; Medical Secretary, BELRA; \\ 8 Portman Street, London, W.1. \\ (Paper delivered at the Symposium on Leprosy Research, London, \\ 20.6.60)
}

\section{Introduction}

Prof. N. A. Torsuev of Rostov on Don has kindly made available 25 printed copies of his Bibliography, which I have translated from the Russian into English and is in your hands, both in the original and in translation, so far as the limited number of original copies will permit. Prof. Torsuev requests that exchange of literature may please be set up with him, from those receiving the Russian Bibliography, and any interested workers. Prof. Torsuev has also kindly sent me a personal communication, giving his own account and his own assessment of the Russian literature, which is of such interest that I first give in this paper his remarks (in my translation.)

\section{N. A. Torsuev on Russian Leprosy Work}

Prof. Torsuev writes as follows:-

Soviet leprologists have published more than 1,200 scientific papers, nearly as much as for the whole pre-revolutionary period, and anti-leprosy organisations have edited more than 20 collections of papers and many monographs. Since 1957 there has been periodical issue of "Scientific Notes of the Leprosy Research Institute". The monographs deal with different problems of leprosy, such as;

I. M. Burakov (1938) "Clinical and Histopathological Changes in the Nose, Throat, and Ear in Leprosy."

G. I. ZhivatovskiI (1938) "The X-ray Picture of Bone Changes in Leprosy."

I. M. Krukover and N. V. Goldfarb (1936). "The Upper Respiratory Tract and Organs of Hearing in Leprosy.",

L. I. Kosolapkina (1943) "Histopathology of Leprosy Lesions."

G. S. Kulesha and I. M. Malinin (1929). "Data on the Study of Leprosy in Kuban'”.

Melek BeK Sultanov (1928) "The Study of Leprotic Dermal Histological Changes, and the Histogenesis of Leproma."

A. N. Mirayants (1934) "Leprosy in Armenia."

N. M. Pavlov (1934) "Ocular Leprosy."

A. M. Falkovich (1939) "Oral Leprosy." and others.

In 1951 and 1952, N. A. Torsuev published two issues of his monograph "Leprosy", and in 1957 "Collective Guide on the Knowledge and Prophylaxis of Leprosy".

The U.S.S.R. has two scientific grades, namely "Candidat" and “Doctor of Medical Sciences", which are given after a public 
defence of the appropriate theses, which must be of high quality. There are more than 50 such dissertations on leprology.

A great part of the published work is devoted to the problem of the organisation of measures to fight leprosy, the form and methods of prophylaxis, and to the study of epidemiological problems. Soviet authors are particularly interested in social and economic factors. In the epidemiology of leprosy the campaign used to be influenced by the idea of isolation of the patient and of treatment in a leprosarium. Now it is based on the dispensary, with all medical and preventive organisations of the Public Health Department working with the dispensaries. In the dermato-venereological dispensaries in the endemic zones, doctors are chosen to take charge of the antileprosy work, with registration of the patients and their relatives, periodical medical examinations, the arranging of dispensary treatment of patients discharged from leprosaria, mass inspections and examinations of the people in dangerously infected areas.

V. I. Kedrovskii has done special work in the microbiology of leprosy and thinks that in an artificial medium the causal organism could transform itself into a more complicated micro-organism of the type of Actinomyces or Streptothrix. There have been several studies of this kind. In 1931, A. A. Shtein and M. I. Tzheperin noted in the lepromin inoculation site the early allergic reaction which was described several years later by J. M. M. Fernandez. A. A. Maximova showed the possibility of modifying the reaction in lepromatous by a repeated intradermal injection of rat leproma ( $M$. lepraemurium). There was a positive Mitsuda when regular lepromin was injected.

I. I. Perevodchikov made a deep study of the reaction of leprosy patients to different pharmaco-dynamic tests. N. A. Chernogubov and N. F. Pavlov (1925) were the first to describe Lichen Leprosus.

N. A. Torsuev (1947) described the leprosy reaction, similar to that of dermatitis herpetiformis Dühring.

G. N. Peshkovskii proved the higher excitability of the sympathetic nervous system in leprosy patients.

A. V. Minaev showed changes in chronaxy, even in parts of the skin apparently clinically healthy.

N. I. Fedorov and others developed the study of nerve symptoms in leprosy.

S. N. Rudchenko and K. I. Vorobieva studied the clinical features of tuberculoid leprosy.

I. F. Alieva described acute and chronic vaginitis of leprosy.

I. I. Nazarov used biomicroscopy to prove the presence of pathological changes in clinically healthy eyes of lepromatous patients, and atrophy and partial destruction in the iris of tuberculoid patients.

Soviet leprologists, I. N. Alamdarov, I. N. Ermakova, N. A. Ivanova, A. I. Kartamishev, L. I. Kosolapkina, N. A. Torsuev, A. A. 
Shtein, and others described the histo-morphological changes in affected nerves and in the apparently healthy skin, fine changes in the carotid sinus, a degenerative process in nerve tissues in autonomic ganglia, the over-compensated growth of the synapses in the aorta, and in the spinal cord ganglia and sympathetic and parasympathetic ganglia; they also showed the condition of the basic argentophilic tissue and expounded the histopathology of the reactive phases of leprosy, and studied different visceral organs. As aid to the diagnosis of early imperceptible skin lesions, N. F. Pavlov described the method of intravenous injection of 6.0 to $10.0 \mathrm{ml}$. of $1 \%$ solution of nicotinic acid.

A lot of work has been done on therapy, which in the USSR is based on the principle of "individualization of the complexes", and on combined treatment.

In 1959 Prof. N. A. Torsuev compiled and edited "Bibliograficheskii Ukazatel Rabot Otechestvennikh Avtorov po Lepre (Bibliographical Index of Papers by Russian Authors, up to the year 1957 inclusive).

\section{Analysis of the Bibliography}

(The above represents the translation of the remarks sent by Prof. Torsuev. Here follows a beginning of an analysis of the papers.)

The Bibliography contains in Section 1 the titles of 1975 papers in Russian. Section 2 contains titles of 664 papers in languages other than Russian.

Allergy and Immunity: 14 papers.

Bibliography: 5 papers

Biography and Obituary: 20 papers.

Biochemistry: 37 papers.

The Antileprosy Campaign: 184 papers.

Upper Respiratory Tract: 55 papers.

Internal Organs: 33 papers.

Geography and Statistics-

Russian Empire and Soviet Union 15 papers

Azerbaidzhan Republic $\quad \ldots \quad \ldots \quad 11$ papers.

Armenian Republic $\quad \ldots \quad \ldots \quad \ldots \quad 13$ papers.

$\begin{array}{lllll}\text { Belorussian Republic } & \ldots & \ldots & \ldots & 3 \text { papers. }\end{array}$

Gruzinsk Republic $\quad \ldots \quad \ldots \quad \ldots \quad 6$ papers.

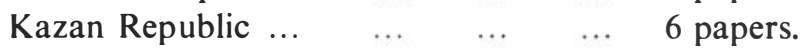

$\begin{array}{lllll}\text { Latvian Republic... } & \ldots & \ldots & \ldots & 6 \text { papers. }\end{array}$

Prebaltic Republic $\quad \ldots \quad \ldots \quad \ldots \quad 34$ papers.

Russian Soviet Federated Socialist Re-

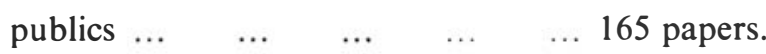




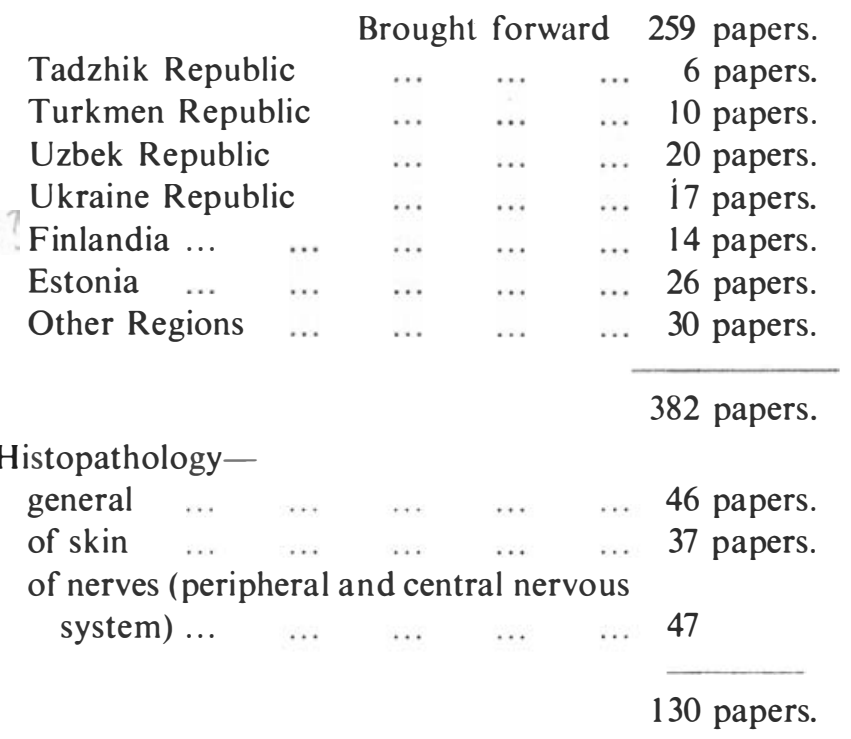

The Eyes: 73 papers.

Diagnosis (Definitive and Differential): 104 papers.

Dissertatiuns of the Soviet Period, for Doctor: 8; for Candidat, 85.

Recovery and Relapse: 17 papers.

History: 70 papers.

Case Histories (see Geography and Statistics): 275 papers.

Classification and Nomenclature: 17 papers.

Bones and Joints: 27 papers.

Blood: 55 papers.

Cultures: 34 papers.

Leprosy and Syringomyelia: 17 papers.

Leprosy and Tuberculosis: 10 papers.

Leprosy and Other Infections: 12 papers.

Lepromin Test: 21 papers.

Leprosaria: 174 papers.

Lepromatous Type (see Case Histories): 36 papers.

Lepromatous Reaction: 24 papers.

Treatment-

general: 72 papers.

hormone preparations: 3 papers.

with "R.D.": 32 papers.

Immunotherapy: 35 papers.

local: 16 papers.

of Reactions: 4 papers.

of Diverse Kinds: 115 papers.

with Sulphones: 36 papers.

Surgical: 5 papers.

Physiotherapy and Orthopaedics: 29 papers. 
Treatment with Phthivazid: 6 papers.

Treatment with Chaulmoogra: 37 papers.

Total No. of Treatment Papers-390.

Microbiology: 62 papers.

Nerve Symptoms: 65 papers.

General Pathology and Pathogenesis: 53 papers.

Antileprosy Campaign Societies: 68 papers.

Official Data: 34 papers.

Leprotic Pemphigus: 3 papers.

Sexual System: 13 papers.

Popular Literature: 13 papers.

Rat Leprosy: 41 papers.

Prophylactic Measures: 29 papers.

Various: 29 papers.

The Mouth: 8 papers.

Directives and Articles of General Nature: 23 papers.

Symposia, Papers, Bulletins: 19 papers.

Cardiovascular System: 10 papers.

Serology: 52 papers.

Conferences, Sessions, Congresses: 32 papers.

Transformation of one Type of the Disease to Another: 10 papers.

Tuberculoid Type (see Case Histories): 21 papers.

Tuberculoid Reactions: 7 papers.

Experimental Leprosy: 38 papers.

Epidemiology: 106 papers. 